Commissioner for Refugees, the decision of the Supreme Court leaves the nation in violation of customary international law and its treaty obligations.

Bona fide interpretation of human rights treaties by the administration and the courts is called for, in accordance with their object and purpose of promoting human rights, even where such interpretation leads to the extraterritoriality of humanitarian obligations of the United States. The established jurisprudence of the Human Rights Committee provides clear guidance and should discourage a narrow territorial construction of the Political Covenant. ${ }^{25}$

Narrow territorial interpretation of human rights treaties is anathema to the basic idea of human rights, which is to ensure that a state should respect human rights of persons over whom it exercises jurisdiction. Because it holds effective power in Haiti, the United States must respect its obligations under the Covenant. Fortunately, the administration has not advanced the claim that it is not obligated to respect its obligations under the pertinent human rights treaties with regard to the land territory of Haiti.

THEODOR MERON*

\title{
HAITI AND THE VALIDITY OF INTERNATIONAL ACTION
}

In December 1990, after decades of dictatorship, the Haitian people overwhelmingly elected Jean-Bertrand Aristide as President. Every aspect of the election was monitored by international organizations and confirmed as "free and fair." Within months, the army, an ill-trained force of some five thousand men, seized power, expelled Aristide, and brutally suppressed popular protest. The Organization of American States and the United Nations Security Council condemned the coup and its aftermath and ordered economic sanctions to dislodge the military. The sanctions failed. On July 31, 1994, the Security Council, acknowledging the gravity of the situation and recognizing that an "exceptional response" was required, passed Resolution 940, authorizing military action. ${ }^{2}$ The legality and wisdom of Resolution 940 has been criticized on the following grounds.

- Internal human rights violations do not constitute "threats to the peaie," the UN Charter's contingency for coercive action. In Haiti, that bridge was long since crossed. The Council's decision to apply economic sanctions - an action that is

\footnotetext{
${ }^{25}$ The United States will, of course, be subject to the Committee's scrutiny of its annual reports under Article 40 and in case of complaints lodged by other state parties under Article 41, which it has accepted.

* I am grateful to Professors Thomas Buergenthal, Louis Henkin and Andreas Lowenfeld for their suggestions.

${ }^{1}$ On international monitoring of the Haitian election of December 16, 1990, see Georges A. Fauriol, Inventing Democracy: The Elections of 1990, in The HaITIAN Challenge: U.S. Foreign POLicy Considerations 53, 57 (Georges A. Fauriol ed., 1993); INTER-AMerican CoMmission on Human RigHTS, ANNUAL REPORT, 1990-91, at.468, OEA/Ser.L/V/II.79, rev.I (1991). For U.S. reaction and assessment, see Howard W. French, Haitians Overwhelmingly Elect Populist Priest to the Presidency, N.Y. Times, Dec. 17, 1990, at A1; Haiti's Choice, and Father Aristide's, N.Y. TIMEs, Dec. 18, 1990, at A24; Haiti's First Freely Elected Leader, WASH. POST, Dec. 20, 1991, at A23. On international election monitoring in general, see W. Michael Reisman, International Election Observation, 4 PACE U. Y.B. INT'L L. 1 (1992).

${ }^{2}$ SC Res. 940 (July 31, 1994), reprinted in N.Y. TimES, July 31, 1994, at A6.
} 
taken under chapter VII - itself had to be premised on a finding that the massive and systematic human rights violations that followed constituted a threat to the peace. In making that determination, the Council was hardly departing from precedent. Since the white minority government of Rhodesia declared its independence and "sovereign" right to suppress the black majority, it has been settled UN law that gross violations of human rights-which the Rhodesian Government insisted were entirely "domestic"-can constitute threats to the peace and can justify action under chapter VII. ${ }^{3}$

- UN military action against Haiti will violate its sovereignty. Whose sovereignty? In modern international law, what counts is the sovereignty of the people and not a metaphysical abstraction called the state. ${ }^{4}$ If the de jure government, which was elected by the people, wants military assistance, how is its sovereignty violated? And if the purpose of the coercion is to reinstate a de jure government elected in a free and fair election after it was ousted by a renegade military, whose sovereignty is being violated? The military's?

- Military actions in the Caribbean never work. Internationally authorized military action is not a panacea for the ills of a society. Its only objective is to reinstate an elected civilian government when nothing else works. That it does not simultaneously reconstruct an economy and solve all the other ills of that society does not mean that it has failed. Would Grenada be better off if it were still under the renegades who murdered Maurice Bishop and seized power? ${ }^{5}$ Would Panama be better off if Noriega were still the dictator? ${ }^{6}$

- A UN-authorized military action is illegitimate if one state provides the bulk of the force. Was Korea or Desert Storm illegitimate? In view of the nature and requirements of military action, and in the absence of a standing international force, one state is often going to provide the bulk of a particular international force.

- Action in Haiti is not in the interest of the United States. People who say this have already dismissed human rights as a valid foreign policy concern. They are entitled to their view but should be estopped from raising it at this late hour. The

\footnotetext{
${ }^{*}$ A concise, early statement of this now-accepted position appears in Myres S. McDougal \& W. Michael Reisman, Rhodesia and the United Nations: The Lawfulness of International Concern, 62 AJIL 1 (1968). The subject receives exhaustive consideration in VERA GowLLAND-DEBBAS, Collective ResPONSES TO IlleGal ACTS IN INTERNATIONAL LAW. UNITED NATIONS ACTION IN THE QUESTION OF SOUTHERN RHODESIA (1990).

' Set generally W. Michael Reisman, Coercion and Self-Determination: Construing Article 2(4), 78 AJIL 642 (1984); Panel, The United Nations Charter and the Use of Force: Is Article 2(4) Still Workable?, 78 ASIL Proc. 68 (1984).

${ }^{5}$ There are many accounts of events under the revolutionary Bishop and New Jewel regimes in Grenada that precipitated the U.S. invasion. See, e.g., ThE GRENADA PAPERS (Paul Seabury \& Walter A. McDougall eds., 1984); ABA Section of INTERnational LaW and PRactice, Report of the COMMITTEE ON GRENADA 1-11 (1984). For differing evaluations of the legality of U.S. action in Grenada, see, e.g., The United States Action in Grenada, 78 AJIL 131 (1984).

"The human rights abuses under General Noriega have been well documented. See AMNESTY INTERNATIONAL USA, PANAMA: AsSAult ON HuMAN Rights (1988); INTER-AMERICAN COMMISSION ON HuMAN Rights, REPORT ON THE SITUATION OF Human Rights In PANAMA, OEA/Ser.L/V.II.76, doc. 16, rev. 2 (2d ed. 1989). One general account of Noriega's rise and rule is in MrchaEl L. CoNNIFF, Panama and the United States: The Forced Alliance 140-72 (1992). For assessment of the legality of the U.S. invasion under international law, see Abraham D. Sofaer, The Legality of the United States Action in Panama, 29 Colum. J. TRANSNAT'L L. 281 (1991) (arguing that U.S. invasion was legal); Louis Henkin, The Invasion of Panama Under Intermational Law: A Dangerous Precedent, id. at 293 (arguing that U.S. invasion violated international law). Other assessments are gathered in Agora: U.S. Forces in Panama: Defenders, Aggressors or Human Rights Activists?, 84 AJIL 494 (1990).
} 
time to have objected was when the imposition of economic sanctions was being considered. Aside from the fact that sanctions are a destructive but uncliscriminating weapon, once a government takes the decision to use them, it has engaged its credibility. At this late moment, the question to ask is not whether the nature of the regime in Haiti is important for U.S. national interests, but whether the credibility of American commitments and demands is. Would the failure of the sanctions the United States has mounted serve our interests? Would the manifest ineffectiveness of the Security Council, of which we are the principal member, in the face of the Haitian military's repudiation of its decisions serve our interests? Would the defeat of U.S. policy by the Haitian military serve U.S. interests?

Much more than Haiti is involved in this incident. The credibility of the United Nations, no less than that of the United States, is at stake here. The Urited States has a major interest in the maintenance of the United Nations as an effective and legitimate instrument of policy. If the United Nations fails to protect elected governments and their peoples from ruthless military renegades, especially when the United Nations has certified the election of those governments as free and fair, it will have no credibility or legitimacy where it counts-with the peoples of the world.

W. Michael Reisman*

\section{The President's Constitutional Authority TO USE LimTted Military Force}

The United States intervention in Haiti concludes another chapter in the development of the constitutional common law of presidential power. The Haiti experience further confirms the constitutional authority of the President to deploy armed forces into hostile foreign environments, and to initiate the use of force without prior, specific congressional authorization. The facts of the situation limit the "precedent" to small-scale interventions where the risk of major military engagements, either initially or upon escalation, is negligible. The cases of largescale hostilities, like Korea, Vietnam and Iraq, are quite different in fact and perhaps also in law. But the Haiti "precedent," coupled with the recent interventions in Grenada and Panama and innumerable examples earlier in history, strongly supports an unqualified presidential power to carry out small-scale military operations in support of foreign policy goals.

The issue is familiar: whether the President has constitutional authority to initiate the use of force without the prior authorization of Congress. The strength of the Haiti precedent is enhanced by the clear, focused debate of this fundamental question in Congress (as well as in the media and among the informed public), which had ample time and opportunity to act. It chose not to act in a timely fashion, and it chose not to assert its prerogative to authorize or reject the President's proposed course of action. In the end, after the intervention was carried out, Congress passed a "sense of the Congress" resolution stating that the Presi-

* Of the Board of Editors. The author wishes to acknowledge the research assistance of Douglas L. Stevick. 